\title{
EFFECT OF SOME TRACE ELEMENTS ON GROWTH, YIELD AND CHEMICAL CONSTITUENTS OF OCIMUM BASILICUM PLANTS
}

\author{
Rania M. Khater* and Wafaa H.A. Abd-Allah \\ Department of Medicinal and Aromatic Plants, Desert Research \\ Center, El-Matareya, Cairo, Egypt \\ *E-mail: dr.raniakhater@yahoo.com
}

$\mathrm{T}$ his research was conducted at El-Qantara Sharq Station, North Sinai, Egypt of Desert Research Center during the two successive seasons of 2014 and 2015. The main objective was to study the effect of microelements [Fe, $\mathrm{Zn}, \mathrm{Mn}$, $\mathrm{Fe}+\mathrm{Zn}, \mathrm{Fe}+\mathrm{Mn}, \mathrm{Zn}+\mathrm{Mn}$ and $\mathrm{Fe}+\mathrm{Zn}+\mathrm{Mn}$, at $50 \mathrm{ppm}$ each], on growth, yield and essential oil content of sweet basil (Ocimum basilicum L.) plant. Treatment of $\mathrm{Fe}+\mathrm{Zn}+\mathrm{Mn}$, at $50 \mathrm{ppm}$ each, produced the highest values of plant growth characters, oil content, $\mathrm{N}, \mathrm{P}, \mathrm{K}, \mathrm{Fe}, \mathrm{Zn}$ and $\mathrm{Mn}$ in plant tissues. Also, this treatment increased the concentrations of 1-linalool to $52.69 \%$ and 1,8 cineole to $25.66 \%$.

Keywords: basil, Ocimum basilicum, Fe, Zn, Mn, 1-linalool, cineole, iron, zinc, manganese, microelements

Basil or sweet basil (Ocimum basilicum L.) is an annual plant belongs to family Lamiacea, native to the tropical regions of southeastern Asia and Africa, that includes around 30 species, which are much differentiated in respect to morpholqgical and chemical features (Vina and Murillo, 2003 and Telci et al., 2006). Sweet basil is the smell of the plant aromatic good savoring, added to food to impart delicious taste and fine odor and basil oil uses are diet benefactor and enters in scented soaps and aromatherapy industry. Sweet basil contains some antibiotics for some types of cancer, antioxidant vitamins, beta-carotene and metal salts; such as Mn, $\mathrm{Cu}, \mathrm{Mg}$ and $\mathrm{K}$ (Marotti et al., 1996). Sweet basil medical antiseptic properties are including the gut, repelling gas and anthelmintic, assistant digestion, lowers cholesterol, blood sugar and tonic for the immune system. It also inserts in the treatment of some diseases; such as intestinal colic, dysentery, boiled chronic diarrhea, vomiting in children, dental pain, kidney stones, headaches, colds, coughs and asthma (Ozcan and Chalchat, 2002 and Sajjadi, 2006). 
Considered nutritious micronutrients; such as iron, zinc and manganese on Egyptian territory continues to drop, as a result of the cultivation of more than one crop on the same area of land during the year, or cropping high productivity and short-lived, leading to the depletion of a large amount of nutrients, lack of interest by adding organic matter that will restore vitality to the soil and make up for the lack of them and increase fertility. High fertilization rates of major elements lead to an increase in yield and thereby increase the amount missing from the micro-earth elements and the expansion in the cultivation of a few desert land fertility. Micronutrients are essential for plant and lack of them reduces the productivity of the crop.

Zinc is an important mineral element to activate many enzymes; such as carbonic anhydrase and alcohol dehydrogenase. It is also necessary for the synthesis of the amino acid tryptophane, which turns into auxin (IAA) that helps to increase the growth of the plant. It was found that in plants suffering from zinc deficiency, auxin concentration in the roots and shoots are very few and has a role in the synthesis of nucleic acids and proteins (Amberger, 1974).

Iron plays an essential and necessary role in many enzymes, especially enzymes intervention or help in the process of respiration, which include system catalase, peroxidase and cytochrome oxidase. The iron participate in the processes of oxidation of these compounds, which is one of the important roles in cell metabolism operations. It is important in the synthesis and maintenance of chlorophyll and the lack of iron at least lead to the appearance of yellowing on the plant. It has also an important role in the representation of nucleic acids and chloroplasts (Nikolic and Kastori, 2000).

Manganese has an important role in the representation of nitrogen within the plant. It also activates a lot of enzymes; such as dehydrogenase and carboxselase and plays a direct role in the processes of oxidation and reduction. Manganese is at the center of the composition of chlorophyll, where the chloroplasts are affected by a lack of manganese, because of its essential role in the fusion of water molecule during the process of photosynthesis (Hill's reaction) (Piagentini et al., 2002 and El-Fouly et al., 2002).

The purpose of this research was to study the effect of microelements on growth, yield and active ingredients of sweet basil (Ocimum basilicum L.) plant to compensate for the lack of microelements in Egyptian land and special desert lands of sandy soil.

\section{MATERIALS AND METHODS}

This work was conducted in the farm of El-Qantara Sharq Station (Desert Research Center), North Sinai, Egypt, during the two successive 
seasons of 2014 and 2015 to study the effect of some microelements on growth, yield and active ingredients of sweet basil.

The seeds of sweet basil plant were obtained from the Medicinal and Aromatic Plants Research Department, Horticulture Institute, Agricultural Research Center, Dokki. Seeds of sweet basil plant were transplanted in the nursery on $1^{\text {st }}$ of March in both seasons of 2014 and 2015. The seedlings were sown in plots $4 \times 4 \mathrm{~m}^{2}$ on $15^{\text {th }}$ of April for both seasons. Each plot contained 66.66 plants and the distance between rows was $60 \mathrm{~cm}$, while the distance between plants was $30 \mathrm{~cm}$. All experimental plots were treated with recommended agriculture practices. The physical and chemical analyses of the experimental farm soil in El-Qantara Sharq Station are shown in table (1).

Table (1). Physical and chemical analysis of the used soil in of El-Qantara Sharq- North Sinai Research Station.

\begin{tabular}{|c|c|c|c|c|c|c|c|}
\hline \multirow[b]{2}{*}{$\begin{array}{l}\text { Mechanical } \\
\text { analysis }\end{array}$} & \multirow[b]{2}{*}{ Value } & \multicolumn{6}{|c|}{ Chemical analysis } \\
\hline & & $\begin{array}{c}\text { Soluble anions } \\
(\mathrm{meq} / \mathrm{l})\end{array}$ & Value & $\begin{array}{c}\text { Soluble cations } \\
(\mathrm{meq} / \mathrm{l})\end{array}$ & Value & $\begin{array}{c}\text { Available } \\
\text { (mg/l) }\end{array}$ & Value \\
\hline Fine sand \% & 43.28 & $\mathrm{CO}_{3}^{-}$ & - & $\mathbf{C a}^{++}$ & 8.92 & $\mathbf{N}$ & 0.16 \\
\hline $\begin{array}{l}\text { Coarse sand } \\
\%\end{array}$ & 42.26 & $\mathrm{Cl}^{-}$ & 9.00 & $\mathbf{M g}^{++}$ & 7.95 & $\mathbf{P}$ & 13.21 \\
\hline $\begin{array}{l}\text { Silt \% } \\
\text { Clay \% } \\
\text { Soil texture }\end{array}$ & $\begin{array}{c}13.28 \\
1.18\end{array}$ & $\begin{array}{c}\mathbf{S O}_{4}^{--} \\
\text {pH } \\
\text { Sandy }\end{array}$ & $\begin{array}{c}25.35 \\
8.29\end{array}$ & $\begin{array}{c}\mathrm{Na}^{+} \\
\mathrm{K}^{+} \\
\text {E.C } \mathbf{m m h o s} / \mathbf{c m}\end{array}$ & $\begin{array}{c}20.42 \\
1.21\end{array}$ & $\begin{array}{c}\mathbf{K} \\
\mathrm{CaCO}_{3} \\
3.85\end{array}$ & $\begin{array}{c}69.67 \\
6.20\end{array}$ \\
\hline
\end{tabular}

The experiment consisted of 8 treatments, the used microelements in this research were:

- Control (distilled water)

- $\mathrm{Fe}+\mathrm{Mn}(50 \mathrm{ppm}+50 \mathrm{ppm})$

- Fe $(50 \mathrm{ppm})$

$-\mathrm{Fe}+\mathrm{Zn}(50 \mathrm{ppm}+50 \mathrm{ppm})$

- $\operatorname{Mn}(50 \mathrm{ppm})$

$-\mathrm{Mn}+\mathrm{Zn}(50 \mathrm{ppm}+50 \mathrm{ppm})$

- $\mathrm{Zn}(50 \mathrm{ppm})$

$-\mathrm{Fe}+\mathrm{Mn}+\mathrm{Zn}(50 \mathrm{ppm}+50$

The sources of $\mathrm{Fe}, \mathrm{Mn}$ and $\mathrm{Zn}$ were commercial products contains $12 \%$ chelated iron, $12 \%$ manganese and $14 \%$ zinc as Fe, Mn and Zn EDTA, respectively, which were obtained from Tabarak Company for Fertilizers and Chemicals (www.tabarakfert.com). Plants were treated with microelements as foliar spray with aqueous solutions two times, the first one was done 45 days after transplanting and the second one 45 days after first cut.

The treatments of the experiment were arranged in complete randomized block design with three replicates. The obtained data were subjected to the statistical analysis according to Snedecor and Cochran 
(1980) and the differences between the means of the treatments were considered by Duncan using Statistix ${ }^{9}$ Analytical Software (1985).

The recorded data included: (i) Vegetative growth parameters (plant height, number of branches per plant and fresh and dry weights of herb per plant and plot). (ii) Essential oil parameters (essential oil percentage, yield and composition). Oil percentage was determined in two cuts according to British Pharmacopoeia (1936), essential oil yield (ml) per plant and per plot were calcutated and oil composition was analyzed by using GC-Mass according to Bunzen et al. (1969) and Hoftman (1967) methods. (iii) Chemical constituents included macroelements (nitrogen, phosphorus and potassium) percentage were determined according Koch and Mc-Meekin (1924), Troug and Mayer (1939) and Brown and Lilleland (1946), respectively. The microelements $(\mathrm{Zn}+\mathrm{Mn}$ and $\mathrm{Fe})$ were determined in the digested samples by atomic absorption by Chaman and Pratt (1961).

The plants were harvested two times through the growing season. The first and second cuts took place on $15^{\text {th }}$ of June and $15^{\text {th }}$ of September in both seasons; respectively.

\section{RESULTS AND DISCUSSION}

\section{Vegetative Growth}

\subsection{Plant height}

Data in table (2) cleared that, all treatments gave a progressive increase in the height of Ocimum basilicum plants, this increasing is significant. Spraying with $\mathrm{Zn}, \mathrm{Mn}$ and $\mathrm{Fe}$ at $50 \mathrm{ppm}$ singly or with each other increased plant height. The best results were achieved by the plants treated with $\mathrm{Zn}+\mathrm{Mn}+\mathrm{Fe}$ together, comparing with the effect of each one. This treatment gave the highest values of 104 and $111 \mathrm{~cm}$ for the first and second cuts, respectively, in first season. Whereas they were 108 and 113.17 $\mathrm{cm}$ at the first and second cuts, in the second season, respectively. These results hold true in the two cuts in two seasons. It is apparent that Fe was the most effective element, when the elements were sprayed separately, followed by data recorded for $\mathrm{Zn}$ then $\mathrm{Mn}$.

Consistent with the these results, many investigators found that $\mathrm{Zn}$ spraying caused on increase in plant height such as Hendawy and Khalid (2005) on Salvia officinalis plant, Abd El-Hady (2007) on barley plant, Pande et al. (2007) on mint plant and Said-Al-Ahl and Omer (2009) on Coriandrum sativum. They concluded that spraying the plants with $\mathrm{Zn}$ significantly increased the height of studied plants. The positive effect of zinc on plant height may be due to that, $\mathrm{Zn}$ accelerated the cell division; it is also controls auxin metabolism (Amberger, 1974).

The present results of manganese are in harmony with those of Gohain and Barbora (2000) on Camellia sinensis and Dewidar (2002) on digitalis plant. They concluded that, spraying the plants with $\mathrm{Mn}$ 
significantly increased the height of studied plants. The role of $\mathrm{Mn}$ of increasing the plant height may be due to that, Mn has important functions in plant metabolism (Amberger, 1974). Therefore, Mn application as foliar spray on plant in this work stimulated the plant height. The results dealing with the effect of $\mathrm{Fe}$ on the plant weight are in agreement with those obtained by Said-Al-Ahl and Omer (2009) on Coriandrum sativum, Said-AlAhl and Mahmoud (2010) on (Ocimum basilicum) and Osińska et al. (2012) on parsley (Petroselinum sativum ssp. crispum). They concluded that, spraying the plants with $\mathrm{Fe}$ significantly increased the height of studied plants. The positive influence at $\mathrm{Fe}$ on plant height, might be due to that, iron had an important role in the biosynthesis of chlorophyll (Amberger, 1974)

Table (2). Effect of some microelements on the plant height of Ocimum basilium during two seasons of 2014 and 2015.

\begin{tabular}{|c|c|c|c|c|}
\hline \multirow[b]{3}{*}{ Treatments } & \multicolumn{4}{|c|}{ Plant height } \\
\hline & \multicolumn{2}{|c|}{$1^{\text {st }}$ Season } & \multicolumn{2}{|c|}{$2^{\text {nd }}$ Season } \\
\hline & $1^{\text {st }}$ cut & $2^{\text {nd }}$ cut & $1^{\text {st }}$ cut & $2^{\text {nd }}$ cut \\
\hline Control (distille & $41.00 \mathrm{G}$ & $43.53 \mathrm{G}$ & $43.00 \mathrm{G}$ & $53.00 \mathrm{H}$ \\
\hline $\mathbf{F e}($ & $83.50 \mathrm{D}$ & $87.67 \mathrm{D}$ & $85.33 \mathrm{D}$ & $90.67 \mathrm{E}$ \\
\hline Mn & $55.83 \mathrm{~F}$ & $61.50 \mathrm{~F}$ & $57.83 \mathrm{~F}$ & $63.83 \mathrm{G}$ \\
\hline $\mathbf{Z n}$ & $74.50 \mathrm{E}$ & $79.00 \mathrm{E}$ & $76.33 \mathrm{E}$ & $82.67 \mathrm{~F}$ \\
\hline ppm) & $94.60 \mathrm{BC}$ & $97.27 \mathrm{~B}$ & $96.33 \mathrm{~B}$ & 104.50 C \\
\hline $\mathrm{Fe}+\mathrm{Zn}$ & $97.27 \mathrm{~B}$ & $100.17 \mathrm{~B}$ & $98.83 \mathrm{~B}$ & $109.67 \mathrm{~B}$ \\
\hline Mn+Zn (50 ppm) & $88.83 \mathrm{CD}$ & $92.50 \mathrm{C}$ & $90.67 \mathrm{C}$ & $100.83 \mathrm{D}$ \\
\hline $\mathrm{Fe}+\mathrm{Mn}+\mathrm{Zn}(50 \mathrm{ppm})$ & $104.00 \mathrm{~A}$ & $111.00 \mathrm{~A}$ & $108.00 \mathrm{~A}$ & 113.17 \\
\hline
\end{tabular}

Means having the same letter within the same column are not significantly different according to LSD for all-pairwise comparisons test at 5\% level of probability.

The results of the mixture of elements are in agreement with these reported by Aziz and El-Sherbeny (2004) on Sideritis montana and Abd ElWahab (2008) on Trachyspermum ammi. They concluded that, spraying the plants with $\mathrm{Zn}, \mathrm{Mn}$ and Fe separated or mixed increased the height of the studied plants. The increased in plant height of sweet basil plants as a result of spraying with mixture of microelements might be due to the effect of microelements on cell division and elongation (Malakouti and Tehrani, 1999).

\subsection{Number of branches}

Data dealing with the effect of microelements on the number of branches per plant are presented in table (3). Spraying of Ocimum basilicum plants with $\mathrm{Zn}, \mathrm{Mn}$ and $\mathrm{Fe}$ at $50 \mathrm{ppm}$ insignificantly increased number of branches per plant when the three elements were sprayed alone or in mixture, compared with the control. Moreover, a significant increase was observed when the treatment of $\mathrm{Zn}+\mathrm{Mn}+\mathrm{Fe}$ was applied on plants in the first 
season, they were 10.67 and 11.33 in the first and second cuts, respectively, and also in the second season they were 11.67 and 12.67 in the two cuts, respectively.

Similar results with Zn treatments were stated by Abd El-Aziz and Balbaa (2007) on Salvia farinacea plant and Said-Al-Ahl and Mahmoud (2010) on Ocimum basilicum. They reported that spraying plants with $\mathrm{Zn}$ significantly increased number of branches per plant. The positive effect of $\mathrm{Zn}$ on number of branches may be explained that, $\mathrm{Zn}$ accelerated the cell division; it is also controls auxin metabolism (Amberger, 1974).

The increase in number of branches per plant due to spraying Mn are in accordance with the finding of El-Sawahly (2000) on Borago officinalis and Hendawy and Khalid (2005) on Salvia officinalis. It concluded that spraying plants with $\mathrm{Mn}$ increased number of branches per plant due to the that, Mn has important function in plant metabolism (Amberger, 1974).

The positive effect of Fe was in harmony with those obtained by Said-Al-Ahl and Omer (2009) on Coriandrum sativum and Said-Al-Ahl and Mahmoud (2010) on Ocimum basilicum. They concluded that foliar spraying with $\mathrm{Fe}$ increased the number of branches per plant. The positive influence of Fe on plant height, might be explained by its vital role in enzymes activity as nitrogenase, catalase and peroxidase (Marschner, 1998).

These remarkable findings of the effect of the mixture of the trace elements are in agreement with those obtained by Aziz and El-Sherbeny (2004) on Sideritis montana and Pande et al. (2007) on mint plant. They cleared that, the mixture of any two of the elements; $\mathrm{Zn}+\mathrm{Mn}, \mathrm{Mn}+\mathrm{Fe}$ and $\mathrm{Zn}+\mathrm{Fe}$ or the mixture of the three elements $\mathrm{Zn}+\mathrm{Mn}+\mathrm{Fe}$, increased number of branches per plant.

Table (3): Effect of some microelements on the number of branches per plant of Ocimum basilicum during two seasons of 2014 and 2015.

\begin{tabular}{|c|c|c|c|c|}
\hline \multirow[b]{3}{*}{ Treatments } & \multicolumn{4}{|c|}{ Number of branches } \\
\hline & \multicolumn{2}{|c|}{$\mathbf{1}^{\text {st }}$ Season } & \multicolumn{2}{|c|}{$2^{\text {nd }}$ Season } \\
\hline & $1^{\text {st }}$ cut & $2^{\text {nd }}$ cut & $1^{\text {st }}$ cut & $2^{\text {nd }}$ cut \\
\hline Control (distilled water) & $4.00 \mathrm{G}$ & $5.00 \mathrm{G}$ & $4.67 \mathrm{E}$ & $5.00 \mathrm{~F}$ \\
\hline $\mathrm{Fe}(50 \mathrm{ppm})$ & 7.33DE & $8.00 \mathrm{D}$ & $8.33 \mathrm{CD}$ & $8.00 \mathrm{D}$ \\
\hline Mn (50 ppm) & $5.67 \mathrm{~F}$ & $6.00 \mathrm{~F}$ & $5.33 \mathrm{E}$ & $6.00 \mathrm{E}$ \\
\hline $\mathrm{Zn}(50$ ppm) & $6.33 \mathrm{EF}$ & $7.33 \mathrm{E}$ & 7.33D & $7.33 \mathrm{D}$ \\
\hline $\mathrm{Fe}+\mathrm{Mn}(50 \mathrm{ppm})$ & $9.00 \mathrm{BC}$ & $9.00 \mathrm{C}$ & $9.00 \mathrm{C}$ & $9.33 \mathrm{C}$ \\
\hline $\mathrm{Fe}+\mathrm{Zn}(50 \mathrm{ppm})$ & $9.67 \mathrm{AB}$ & $10.00 \mathrm{~B}$ & $10.33 \mathrm{~B}$ & $10.33 \mathrm{~B}$ \\
\hline$M n+Z n(50$ ppm) & $8.33 \mathrm{CD}$ & $9.00 \mathrm{C}$ & $8.67 \mathrm{C}$ & $9.33 \mathrm{C}$ \\
\hline $\mathrm{Fe}+\mathrm{Mn}+\mathrm{Zn}(50 \mathrm{ppm})$ & $10.67 \mathrm{~A}$ & $11.33 \mathrm{~A}$ & $11.67 \mathrm{~A}$ & $12.67 \mathrm{~A}$ \\
\hline
\end{tabular}

Means having the same letter within the same column are not significantly different according to LSD for all-pairwise comparisons test at 5\% level of probability.

Egyptian J. Desert Res., 67, No. 1, 1-23 (2017) 


\subsection{Fresh and dry weights}

Data presented the plant herb yield are shown in table (4). Results showed that, spraying sweet basil with trace elements produced heaviest fresh and dry weights of herb per plant and plot compared with the untreated plants. Spraying sweet basil with microelements ( $\mathrm{Zn}, \mathrm{Mn}$ or Fe at $50 \mathrm{ppm}$ ), separately or in mixture, significantly increased the fresh and dry weights of herb per plant and plot, in both cuts and seasons, compared with the untreated plants. Also, results showed that, $\mathrm{Fe}$ alone significantly increased the fresh and dry weights of plant compared with $\mathrm{Zn}$ or $\mathrm{Mn}$ alone. The mixture of $\mathrm{Fe}+\mathrm{Zn}$ gave higher values of fresh and dry weights per plant and feddan compared to the other two mixtures. The treatment of $\mathrm{Zn}+\mathrm{Mn}+\mathrm{Fe}$ produced the highest values the fresh and dry weights of herb per plant and plot, the least value was obtained from control plants. This was obvious in both cuts and seasons of the experiment. The differences between treatments and control were significant, when the experiment was repeated in the two cuts and two seasons, similar data were observed.

The remarkable findings of the effect of $\mathrm{Zn}$ on fresh and dry weights of plants are in agreement with those obtained by Grejtovsky et al. (2006) on Matricaria chamomilla, Abd El-Aziz and Balbaa (2007) on Salvia farinacea and Akhtar et al. (2009) on Mentha piperita. They concluded that foliar sprays of $\mathrm{Zn}$ significantly increased the fresh and dry weights of the studied plants. The simulative effect of $\mathrm{Zn}$ application on the dry weight may be due to its indirect influence on the biosynthesis of oxidation and reduction enzymes of photosynthesis. Amberger (1974) reported that, Zn plays a role in metabolic pathway from tryptophan to IAA.

As for the effect of Mn on increasing the fresh and dry weights of herb per plant, in this respect, El-Sawahly (2000) on Borago officinalis and Abd El-Wahab (2008) on Ajowan plant concluded that foliar sprays of Mn significantly increased the fresh and dry weights of the studied plants. The increment in leaf dry weight may be due to that $\mathrm{Mn}$ application has important functions in plant metabolism (Amberger, 1974). Also, Mengel and Kirkby (1978) concluded that, $\mathrm{Mn}$ in some way involved in the oxidation/reduction processes in photosynthetic electron transport system.

Fe stimulated the fresh and dry weights of plants. In this concern, Reffat and Balbaa (2001) on lemongass, Kassem (2002) on rosemary, Hashem (2007) on thyme and Abd El-Wahab (2008) on Trachyspermum ammi. They concluded that spraying with Fe significantly increased the fresh and dry weights per plant and per plot. This increase in weight by $\mathrm{Fe}$ spraying could be explained in the light of its role in the oxidation-reduction reactions in respiration and photosynthesis and due to that iron has a number of important function roles in plant, and hence it causes a marked effect on photosynthetic efficiency (Gauch, 1957). 
Table (4). Effect of some microelements on the fresh and dry weights of herb per plant $(\mathrm{g})$ and per plot $(\mathrm{kg})$ of Ocimum basilicum during two seasons of 2014 and 2015.

\begin{tabular}{|c|c|c|c|c|c|c|c|c|}
\hline \multirow[b]{3}{*}{ Treatments } & \multicolumn{2}{|c|}{$\begin{array}{l}\text { Fresh weight of } \\
\text { herb per plant (g) }\end{array}$} & \multicolumn{2}{|c|}{$\begin{array}{c}\text { Fresh weight of } \\
\text { herb per plot } \\
(\mathrm{kg})\end{array}$} & \multicolumn{2}{|c|}{$\begin{array}{l}\text { Dry weight of herb per } \\
\text { plant (g) }\end{array}$} & \multicolumn{2}{|c|}{$\begin{array}{c}\text { Dry weight of } \\
\text { herb per plot } \\
(\mathrm{kg})\end{array}$} \\
\hline & \multicolumn{8}{|c|}{$1^{\text {st }}$ Season } \\
\hline & $1^{\text {st }}$ cut & $2^{\text {nd }}$ cut & $1^{\text {st }}$ cut & $2^{\text {nd }}$ cut & $1^{\text {st }}$ cut & $2^{\text {nd }}$ cut & $1^{\text {st }}$ cut & $2^{\text {nd }}$ cut \\
\hline $\begin{array}{l}\text { Control (distilled } \\
\text { water) }\end{array}$ & $123.93 \mathrm{G}$ & $132.10 \mathrm{G}$ & $6.20 \mathrm{G}$ & $6.61 \mathrm{G}$ & $42.33 \mathrm{G}$ & $42.50 \mathrm{~F}$ & $2.12 \mathrm{G}$ & $2.13 \mathrm{~F}$ \\
\hline Fe (50 ppm) & 213.67D & $228.29 \mathrm{D}$ & $10.68 \mathrm{D}$ & $11.41 \mathrm{D}$ & $72.33 \mathrm{D}$ & $78.50 \mathrm{CD}$ & $3.62 \mathrm{D}$ & $3.93 \mathrm{CD}$ \\
\hline $\operatorname{Mn}(50$ ppm) & $152.00 \mathrm{~F}$ & $160.80 \mathrm{~F}$ & $7.60 \mathrm{~F}$ & $8.04 \mathrm{~F}$ & $52.67 \mathrm{~F}$ & $56.83 \mathrm{E}$ & $2.63 \mathrm{~F}$ & $2.84 \mathrm{E}$ \\
\hline Zn (50 ppm) & $183.67 \mathrm{E}$ & $207.09 \mathrm{E}$ & $9.18 \mathrm{E}$ & $10.35 \mathrm{E}$ & $62.17 \mathrm{E}$ & 73.17D & $3.11 \mathrm{E}$ & $3.66 \mathrm{D}$ \\
\hline $\mathbf{F e}+\mathrm{Mn}(50$ ppm) & $252.00 \mathrm{C}$ & $266.81 \mathrm{C}$ & $12.60 \mathrm{C}$ & $13.34 \mathrm{C}$ & $85.67 \mathrm{~B}$ & $89.20 \mathrm{~B}$ & $4.28 \mathrm{~B}$ & $4.46 \mathrm{~B}$ \\
\hline $\mathrm{Fe}+\mathrm{Zn}(50$ ppm) & $268.83 \mathrm{~B}$ & $279.02 \mathrm{~B}$ & 13.44B & $13.95 \mathrm{~B}$ & $87.00 \mathrm{~B}$ & $92.67 \mathrm{~B}$ & $4.35 \mathrm{~B}$ & $4.63 \mathrm{~B}$ \\
\hline $\mathrm{Mn}+\mathrm{Zn}(50$ ppm) & $240.50 \mathrm{C}$ & $256.62 \mathrm{C}$ & $12.03 \mathrm{C}$ & $12.83 \mathrm{C}$ & $78.83 \mathrm{C}$ & $79.50 \mathrm{C}$ & $3.94 \mathrm{C}$ & $3.98 \mathrm{C}$ \\
\hline \multirow[t]{3}{*}{$\begin{array}{l}\text { Fe+Mn+Zn (50 } \\
\text { ppm) }\end{array}$} & $288.83 \mathrm{~A}$ & $293.28 \mathrm{~A}$ & $14.44 \mathrm{~A}$ & $14.66 \mathrm{~A}$ & $97.00 \mathrm{~A}$ & $101.17 \mathrm{~A}$ & $4.85 \mathrm{~A}$ & $5.06 \mathrm{~A}$ \\
\hline & \multicolumn{8}{|c|}{$2^{\text {nd }}$ Season } \\
\hline & $1^{\text {st }}$ cut & $2^{\text {nd }}$ cut & $1^{\text {st }}$ cut & $2^{\text {nd }}$ cut & $1^{\text {st }}$ cut & $2^{\text {nd }}$ cut & $1^{\text {st }}$ cut & $2^{\text {nd }}$ cut \\
\hline $\begin{array}{l}\text { Control (distilled } \\
\text { water) }\end{array}$ & $165.60 \mathrm{E}$ & $177.11 \mathrm{G}$ & $8.28 \mathrm{E}$ & $8.86 \mathrm{G}$ & $58.77 \mathrm{G}$ & $60.83 \mathrm{G}$ & $2.94 \mathrm{G}$ & $3.04 \mathrm{G}$ \\
\hline Fe (50 ppm) & $293.67 \mathrm{C}$ & $302.82 \mathrm{D}$ & $14.68 \mathrm{C}$ & $15.14 \mathrm{D}$ & 100 & 104 & $5.01 \mathrm{D}$ & $5.20 \mathrm{D}$ \\
\hline $\operatorname{Mn}(50$ ppm) & $192.00 \mathrm{E}$ & $210.66 \mathrm{~F}$ & $9.60 \mathrm{E}$ & $10.53 \mathrm{~F}$ & $69.10 \mathrm{~F}$ & $69.67 \mathrm{~F}$ & $3.46 \mathrm{~F}$ & $3.48 \mathrm{~F}$ \\
\hline Zn (50 ppm) & $245.50 \mathrm{D}$ & $274.70 \mathrm{E}$ & $12.28 \mathrm{D}$ & $13.74 \mathrm{E}$ & $89.17 \mathrm{E}$ & $93.83 \mathrm{E}$ & $4.46 \mathrm{E}$ & $4.69 \mathrm{E}$ \\
\hline $\mathbf{F e}+\mathrm{Mn}(50 \mathrm{ppm})$ & $342.00 \mathrm{~B}$ & $352.18 \mathrm{~B}$ & $17.10 \mathrm{~B}$ & $17.61 \mathrm{~B}$ & 116.33B & $119.00 \mathrm{BC}$ & $5.82 \mathrm{~B}$ & $5.95 \mathrm{BC}$ \\
\hline $\mathrm{Fe}+\mathrm{Zn}(50 \mathrm{ppm})$ & $355.17 \mathrm{~B}$ & $364.64 \mathrm{~B}$ & $17.76 \mathrm{~B}$ & $18.23 \mathrm{~B}$ & 119.67B & $123.33 \mathrm{~B}$ & $5.98 \mathrm{~B}$ & $6.17 \mathrm{~B}$ \\
\hline $\mathrm{Mn}+\mathrm{Zn}(50 \mathrm{ppm})$ & $328.17 \mathrm{~B}$ & $335.68 \mathrm{C}$ & $16.41 \mathrm{~B}$ & $16.78 \mathrm{C}$ & $110.20 \mathrm{C}$ & $114.00 \mathrm{C}$ & $5.51 \mathrm{C}$ & $5.70 \mathrm{C}$ \\
\hline $\begin{array}{l}\text { Fe+Mn+Zn (50 } \\
\text { ppm) }\end{array}$ & $386.67 \mathrm{~A}$ & $387.13 \mathrm{~A}$ & $19.33 \mathrm{~A}$ & $19.36 \mathrm{~A}$ & $126.67 \mathrm{~A}$ & $131.17 \mathrm{~A}$ & $6.33 \mathrm{~A}$ & $6.56 \mathrm{~A}$ \\
\hline
\end{tabular}

Means having the same letter within the same column are not significantly different according to LSD for all-pairwise comparisons test at 5\% level of probability.

As the mixture of microelements was studied, the stimulatory effect was observed by many investigators, such as El-Sawahly (2000) on Borago officinalis and Gharib (2001) on Tagetes minuta. They concluded that the mixture of any two elements $(\mathrm{Zn}+\mathrm{Mn}$ or $\mathrm{Mn}+\mathrm{Fe}$ or $\mathrm{Zn}+\mathrm{Fe})$ resulted in significantly increase in the day matter content compared with the effect of any separate element or control. They added that the mixture of the three elements $(\mathrm{Zn}+\mathrm{Mn}+\mathrm{Fe})$ resulted in a significant increase in the dry matter content compared with the effect of any separate or two elements. 


\section{Active Ingredients}

\subsection{Volatile oil}

Data in table (5) show that, there is a progressive increase in the volatile oil percentage of Ocimum basilicum plant during both seasons. Spraying with $\mathrm{Zn}, \mathrm{Mn}$ and $\mathrm{Fe}$ at $50 \mathrm{ppm}$ individually or in combination increased the volatile oil percentage in most cases. The best results were obtained by spraying plants with $\mathrm{Zn}+\mathrm{Mn}+\mathrm{Fe}$ jointly, comparing with the effect of the three elements alone. It is obvious that $\mathrm{Fe}$ was the most effective element, when the elements were sprayed separately, followed by $\mathrm{Zn}$ then Mn. This was recorded in the two cuts and two seasons.

Table (5). Effect of some microelements on the oil percentage based on dry weight basis of Ocimumbasilicum during two seasons of 2014 and 2015.

\begin{tabular}{lcccc}
\hline \multirow{2}{*}{ Characters } & \multicolumn{4}{c}{ Oil percentage } \\
\cline { 2 - 5 } Treatments & \multicolumn{2}{c}{ 1st Season } & \multicolumn{2}{c}{$\mathbf{2}^{\text {nd }}$ Season } \\
\cline { 2 - 5 } & $\mathbf{1}^{\text {st }}$ cut & $\mathbf{2}^{\text {nd }}$ cut & $\mathbf{1}^{\text {st }}$ cut & $\mathbf{2}^{\text {nd }}$ cut \\
\hline Control (distilled water $)$ & $0.067 \mathrm{E}$ & $0.110 \mathrm{H}$ & $0.080 \mathrm{H}$ & $0.087 \mathrm{G}$ \\
Fe (50 $\mathbf{~ p p m ) ~}$ & $0.127 \mathrm{D}$ & $0.213 \mathrm{E}$ & $0.167 \mathrm{E}$ & $0.183 \mathrm{E}$ \\
Mn (50 $\mathbf{~ p p m ) ~}$ & $0.083 \mathrm{E}$ & $0.133 \mathrm{G}$ & $0.103 \mathrm{G}$ & $0.127 \mathrm{~F}$ \\
$\mathbf{Z n}(\mathbf{5 0} \mathbf{~ p p m )}$ & $0.110 \mathrm{D}$ & $0.170 \mathrm{~F}$ & $0.130 \mathrm{~F}$ & $0.147 \mathrm{~F}$ \\
$\mathbf{F e}+\mathbf{M n}(\mathbf{5 0} \mathbf{~ p p m )}$ & $0.187 \mathrm{~B}$ & $0.273 \mathrm{C}$ & $0.217 \mathrm{C}$ & $0.237 \mathrm{C}$ \\
$\mathbf{F e}+\mathbf{Z n}(\mathbf{5 0} \mathbf{~ p p m )}$ & $0.210 \mathrm{~A}$ & $0.307 \mathrm{~B}$ & $0.240 \mathrm{~B}$ & $0.260 \mathrm{~B}$ \\
$\mathbf{M n + Z n}(\mathbf{5 0} \mathbf{~ p p m})$ & $0.160 \mathrm{C}$ & $0.243 \mathrm{D}$ & $0.190 \mathrm{D}$ & $0.210 \mathrm{D}$ \\
$\mathbf{F e}+\mathbf{M n}+\mathbf{Z n}(\mathbf{5 0} \mathbf{~ p p m})$ & $0.223 \mathrm{~A}$ & $0.327 \mathrm{~A}$ & $0.260 \mathrm{~A}$ & $0.310 \mathrm{~A}$ \\
\hline
\end{tabular}

Means having the same letter within the same column are not significantly different according to LSD for all-pairwise comparisons test at 5\% level of probability.

Data dealing with effect of micronutrients on the volatile oil content of herb per plant and per plot in both seasons are shown in table (6). It is evident that, spraying sweet basil plants with microelements ( $\mathrm{Zn}, \mathrm{Mn}$ or Fe at $50 \mathrm{ppm}$ ) alone or in mixture significantly increased the volatile oil content of herb per plant and per plot, in the two cuts and two seasons, compared with the untreated plants. Spraying Fe alone obtained the greatest values in comparison with $\mathrm{Zn}$ or $\mathrm{Mn}$ alone. The mixture of $\mathrm{Zn}+\mathrm{Fe}$ gave higher values of volatile oil content in comparison to the other two mixtures. Spraying sweet basil plants with $\mathrm{Zn}+\mathrm{Mn}+\mathrm{Fe}$ together produced the highest values of volatile oil percentage. This was obvious in the two cuts and two seasons.

The increase in the volatile oil content of leaves by spraying $\mathrm{Zn}$ are in accordance with the findings of Akhtar et al. (2009) on Mentha piperita, Said-Al-Ahl and Omer (2009) on Coriandrum sativum plant and Nasiri et al. (2010) on Matricaria chamomilla. They reported that, the application of $\mathrm{Zn}$ 
(50 ppm) to plants caused an increase in volatile oil content if compared with the untreated ones.

The obtained results of the effect of $\mathrm{Mn}$ on the volatile oil yield are in accordance with those of Said-Al-Ahl and Mahmoud (2010) on Ocimum basilicum plant. They reported that spraying plant with $\mathrm{Mn}(50 \mathrm{ppm})$ caused a significant increase in the volatile oil content. The present data of $\mathrm{Fe}$ agreed with those of Abd El-Wahab (2008) on Trachspermum ammi and Nasiri et al. (2010) on Matricaria chamomilla, they found that iron application on plant caused an increment in the volatile oil content.

As the mixture of microelements was studied, this activation effect was observed by many investigators, such as Abd El-Wahab (2008) on Trachspermum ammi and Kalidasu et al. (2008) on Coriandrum sativum. They indicated that spraying with $\mathrm{Fe}+\mathrm{Mn}, \mathrm{Fe}+\mathrm{Zn}$ and $\mathrm{Zn}+\mathrm{Mn}+\mathrm{Fe}$ produced the highest volatile oil content per plant and plot compared with the other treatments.

\subsection{Volatile oil yield}

Data of the volatile oil yield productivity are shown in table (6). Results show that, spraying sweet basil plants with some trace elements produced the heaviest volatile oil yield per plant as compared with untreated plants. Statistical analysis showed a highly significant increase in both seasons. Fe alone had significantly increased the volatile oil yield per plant compared with $\mathrm{Zn}$ or $\mathrm{Mn}$ alone. These results are true in the two cuts and two seasons.

All mixtures resulted in highly significant increases, compared with the control plants. The best results were obtained from the use of the three elements together on sweet basil plants followed by $\mathrm{Fe}$ with $\mathrm{Zn}$ or $\mathrm{Mn}$ treatments and to a less extent the mixture of $\mathrm{Zn}+\mathrm{Mn}$. The increase in the volatile oil yield per plant in treatments of Fe alone or $\mathrm{Zn}+\mathrm{Mn}+\mathrm{Fe}$ together may be attributed to the increase in the number of branches and leaves per plant resulted from these treatments.

Data dealing with the effect of micronutrients on the volatile oil yield per plot in both seasons are shown in table (6). The results show that, spraying sweet basil plants with trace elements produced the highest volatile oil yield per plant and per plot compared with the untreated ones. Statistical analysis showed that there is a highly significant increase in both seasons. Fe alone significantly increased the volatile oil yield per plant and per plot compared with $\mathrm{Zn}$ or Mn alone. These results are true in the both seasons.

All mixtures resulted in highly significant increase, compared with the control. The best results were obtained from using of three elements together on plant; followed by $\mathrm{Zn}+\mathrm{Fe}$ treatment and to a less extent the mixture of $\mathrm{Zn}+\mathrm{Mn}$. The increase in the volatile oil yield per plant and per plot in treatments of Fe alone or $\mathrm{Zn}+\mathrm{Mn}+\mathrm{Fe}$ together may be due to the increase in the number of branches and leaves per plant and plot resulted from these treatments.

Egyptian J. Desert Res., 67, No. 1, 1-23 (2017) 
These remarkable findings of the effect of $\mathrm{Zn}$ on herb yield are in agreement with El-Sawi and Mohamed (2002) on cumin plant and Said-AlAhl and Mahmoud (2010) on Ocimum basilicum. They reported that, the application of $\mathrm{Zn}$ at $50 \mathrm{ppm}$ to the plants caused an increased in the volatile oil yield if compared with the untreated plants.

The obtained results for the effect of $\mathrm{Mn}$ on volatile oil yield are in accordance with those of Abd El-Aziz (2000) on basil plant and Eisa (2000) on fennel plant. They reported that spraying plants with Mn caused a significant increase in the volatile oil yield.

The present data of Fe agreed with those of Zehtab-Salmasi et al. (2008) on Mentha piperita and Said-Al-Ahland Mahmoud (2010) on Ocimum basilicum. They found that iron application on plant caused an increment in the volatile oil yield.

Table (6). Effect of some microelements on the Volatile oil yield per plant and per plot $(\mathrm{ml})$ of Ocimum basilicum during two seasons of 2014 and 2015.

\begin{tabular}{|c|c|c|c|c|}
\hline \multirow{3}{*}{$\begin{array}{l}\text { Characters } \\
\text { Treatments }\end{array}$} & \multicolumn{2}{|c|}{$\begin{array}{c}\text { Volatile oil yield per } \\
\text { plant (ml) }\end{array}$} & \multicolumn{2}{|c|}{$\begin{array}{l}\text { Volatile oil yield } \\
\text { per plot }(\mathrm{ml})\end{array}$} \\
\hline & \multicolumn{4}{|c|}{$1^{\text {st }}$ Season } \\
\hline & $1^{\text {st }}$ cut & $2^{\text {nd }}$ cut & $1^{\text {st }}$ cut & $2^{\text {nd }}$ cut \\
\hline Control (distilled water ) & $0.030 \mathrm{G}$ & $0.047 \mathrm{H}$ & $1.50 \mathrm{G}$ & $2.35 \mathrm{H}$ \\
\hline $\mathrm{Fe}(50 \mathrm{ppm})$ & $0.093 \mathrm{E}$ & $0.167 \mathrm{E}$ & $4.65 \mathrm{E}$ & $8.35 \mathrm{E}$ \\
\hline Mn (50 ppm) & $0.043 \mathrm{G}$ & $0.073 \mathrm{G}$ & $2.15 \mathrm{G}$ & $3.65 \mathrm{G}$ \\
\hline Zn (50 ppm) & $0.070 \mathrm{~F}$ & $0.127 \mathrm{~F}$ & $3.50 \mathrm{~F}$ & $6.35 \mathrm{~F}$ \\
\hline Fe+Mn (50 ppm) & $0.157 \mathrm{C}$ & $0.243 \mathrm{C}$ & $7.85 \mathrm{C}$ & $12.15 \mathrm{C}$ \\
\hline $\mathrm{Fe}+\mathrm{Zn}(50 \mathrm{ppm})$ & $0.183 \mathrm{~B}$ & $0.287 \mathrm{~B}$ & $9.15 \mathrm{~B}$ & $14.35 \mathrm{~B}$ \\
\hline Mn+Zn (50 ppm) & $0.123 \mathrm{D}$ & $0.193 \mathrm{D}$ & $6.15 \mathrm{D}$ & $9.65 \mathrm{D}$ \\
\hline \multirow[t]{2}{*}{$\mathrm{Fe}+\mathrm{Mn}+\mathrm{Zn}(50 \mathrm{ppm})$} & $0.217 \mathrm{~A}$ & $0.333 \mathrm{~A}$ & $10.85 \mathrm{~A}$ & $16.65 \mathrm{~A}$ \\
\hline & \multicolumn{4}{|c|}{$2^{\text {nd }}$ Season } \\
\hline Control (distilled water ) & $0.047 \mathrm{H}$ & $0.053 \mathrm{G}$ & $2.35 \mathrm{H}$ & $2.65 \mathrm{G}$ \\
\hline Fe (50 ppm) & $0.167 \mathrm{E}$ & $0.190 \mathrm{E}$ & $8.35 \mathrm{E}$ & $9.50 \mathrm{E}$ \\
\hline $\operatorname{Mn}(50$ ppm) & $0.073 \mathrm{G}$ & $0.087 \mathrm{G}$ & $3.65 \mathrm{G}$ & $4.35 \mathrm{G}$ \\
\hline Zn (50 ppm) & $0.117 \mathrm{~F}$ & $0.137 \mathrm{~F}$ & $5.85 \mathrm{~F}$ & $6.85 \mathrm{~F}$ \\
\hline $\mathrm{Fe}+\mathrm{Mn}(50$ ppm) & $0.253 \mathrm{C}$ & $0.283 \mathrm{C}$ & $12.65 \mathrm{C}$ & $14.15 \mathrm{C}$ \\
\hline $\mathrm{Fe}+\mathrm{Zn}(50 \mathrm{ppm})$ & $0.290 \mathrm{~B}$ & $0.323 \mathrm{~B}$ & $14.50 \mathrm{~B}$ & $16.15 \mathrm{~B}$ \\
\hline $\mathrm{Mn}+\mathrm{Zn}(50 \mathrm{ppm})$ & $0.210 \mathrm{D}$ & $0.240 \mathrm{D}$ & $10.50 \mathrm{D}$ & $12.00 \mathrm{D}$ \\
\hline $\mathrm{Fe}+\mathrm{Mn}+\mathrm{Zn}(50 \mathrm{ppm})$ & $0.330 \mathrm{~A}$ & $0.407 \mathrm{~A}$ & $16.50 \mathrm{~A}$ & $20.35 \mathrm{~A}$ \\
\hline
\end{tabular}

Means having the same letter within the same column are not significantly different according to LSD for all-pairwise comparisons test at 5\% level of probability.

As the mixture of microelements was studied, the stimulatory effect was observed by many investigators, such as Abd El-Wahab (2008) on 
Trachyspemum ammi, Zehtab-Salmasi et al. (2008) on Mentha piperita andYounis et al. (2013) on Rosa hybrid, cvs. They indicated that spraying with $\mathrm{Fe}+\mathrm{Mn}, \mathrm{Fe}+\mathrm{Zn}$ and $\mathrm{Zn}+\mathrm{Mn}+\mathrm{Fe}$ produced the highest volatile oil yield per plant and plot compared with the other treatments.

\subsection{Volatile oil components}

Chromatographic analysis of the volatile samples taken from the second cut in the second season are shown in table (7). It is clear that 1linalool is the main component of sweet basil oil followed by 1,8 cineole (the second component) and estragole (the third component), while other components such as $\alpha$-phellandrene, camphene, trans sabinenehydrate, $\alpha-$ terpineol .... etc. constitute relatively small percentages of volatile oil in the second season.

Concerning the effect of some microelements on the different volatile oil components in both seasons are shown in table (7) and fig. (1, 2, $3,4,5,6,7,8)$. It could be observed that for L-linalool is; the main component of sweet basil., when spraying plants with $\mathrm{Zn}, \mathrm{Mn}$ and $\mathrm{Fe}$ at 50 ppm singly or in mixture, increased its percentage in all treatments. The best results were obtained by the plants with $\mathrm{Zn}+\mathrm{Mn}+\mathrm{Fe}$. Comparing the effect of the three elements, it is obvious that $\mathrm{Fe}$ was the most effective element, when the elements were sprayed separately, followed by $\mathrm{Zn}$ then Mn. Data recorded in the second season were confirmed by those of the first one, where microelements improved the quality of the volatile oil at all treatments.

1,8 cineole; the second important volatile oil component, percentages in sweet basil oil increased by treating the plants with the micronutrients separately or in mixture. The best results were obtained by the plants treated with $\mathrm{Zn}+\mathrm{Mn}+\mathrm{Fe}$ together. Comparing the effect of the three elements, it is obvious that Fe was the most effective element, when the elements were sprayed separately, followed by $\mathrm{Zn}$ then Mn.

Estragole is the third important volatile oil component, percentages in sweet basil oil decreased by treating the plants by $\mathrm{Mn}$ or Fe at $50 \mathrm{ppm}$. The treatment of $\mathrm{Zn}+\mathrm{Mn}+\mathrm{Fe}$ together gave the lowest value of estragole. Data recorded in the second season were confirmed by the improved quality of the volatile oil at all treatments. 


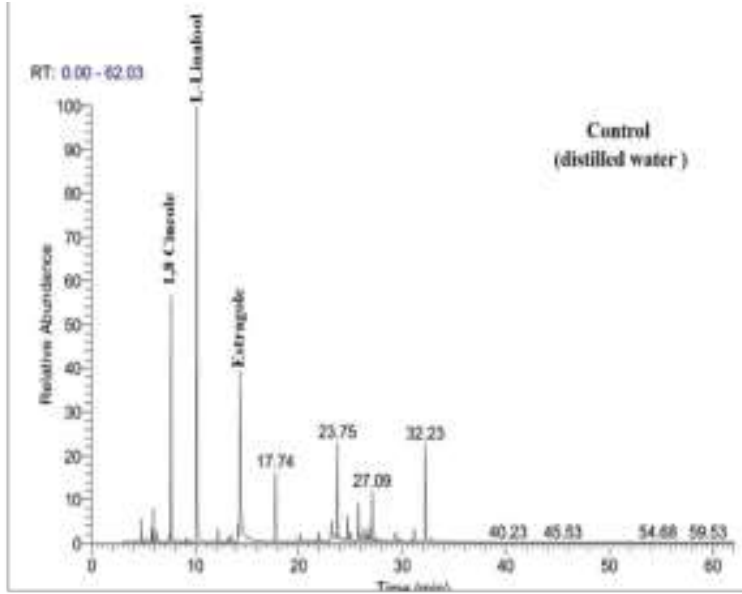

Fig (1): chromatogram of Ocimum bosilicum, L. distilled from control plants during the second cut in the second season 2015.

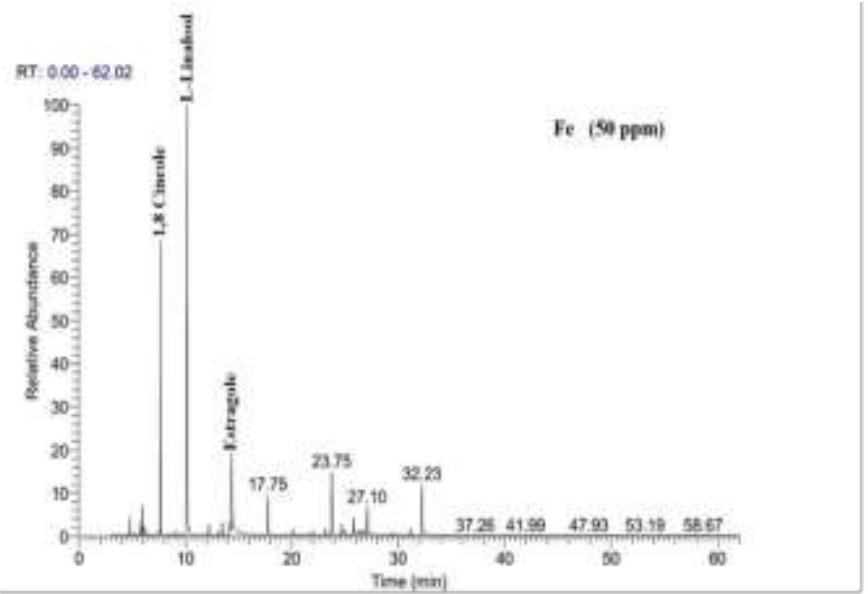

Fig (2): chromatogram of Ocimum bosilicum, L. distilled from plants treated by $\mathrm{Fe}(50 \mathrm{ppm})$ during the second cut in the second season 2015.

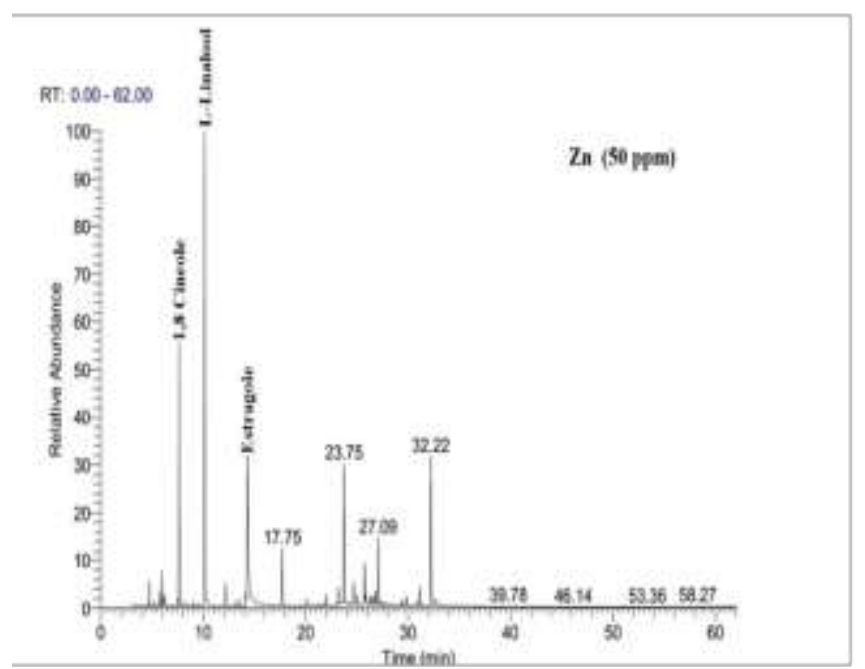

Fig (4): chromatogram of Ocimum bosilicum, L distilled from plants treated by $2 n(50 \mathrm{ppm})$ during the second cut in the second season 2015.

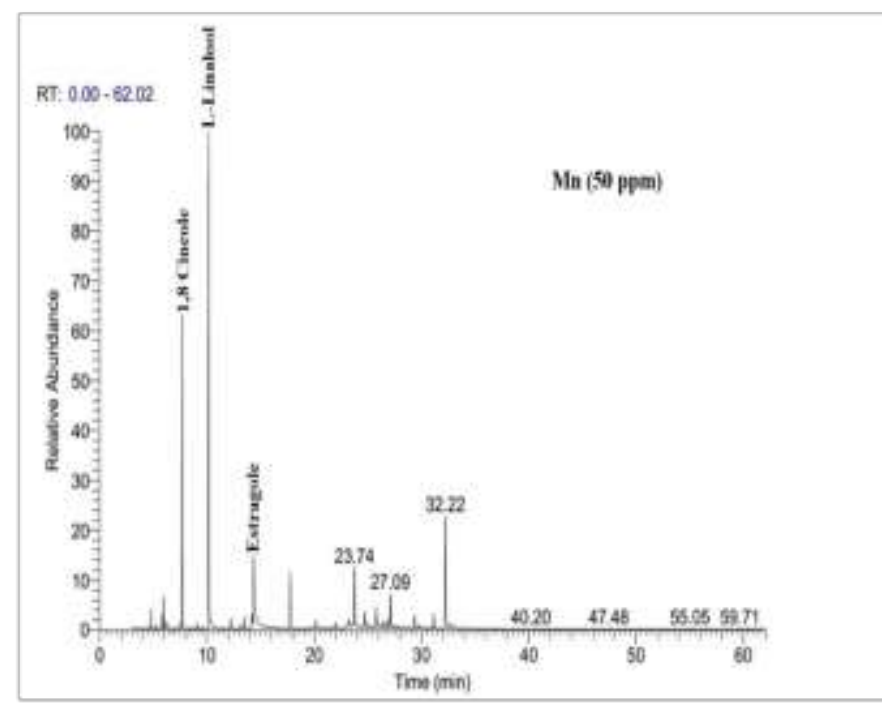

Fig (3): chromatogram of Ocimum basilicum, L distilled from plants treated by $\mathrm{Mn}$ (50 ppm) during the second cut in the second season 2015.

Egyptian J. Desert Res., 67, No. 1, 1-23 (2017) 


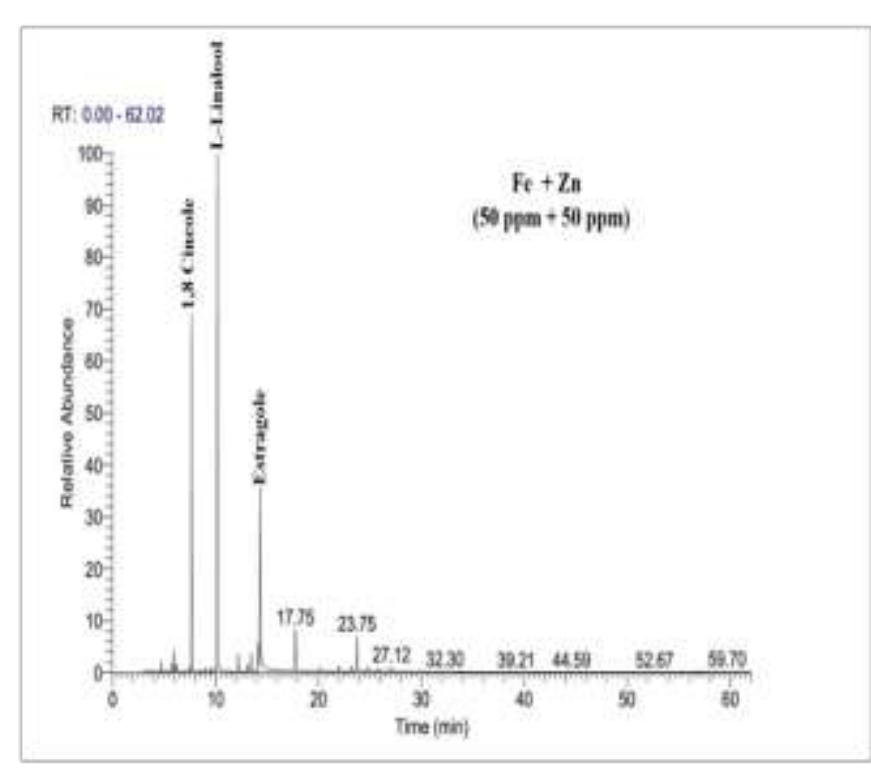

Fig (5): chromatogram of Ocimum bosilicum, L. distilled from plants treated by $\mathrm{Fe}+\mathrm{Zn}(50 \mathrm{ppm})$ during the second cut in the second season 2015 .

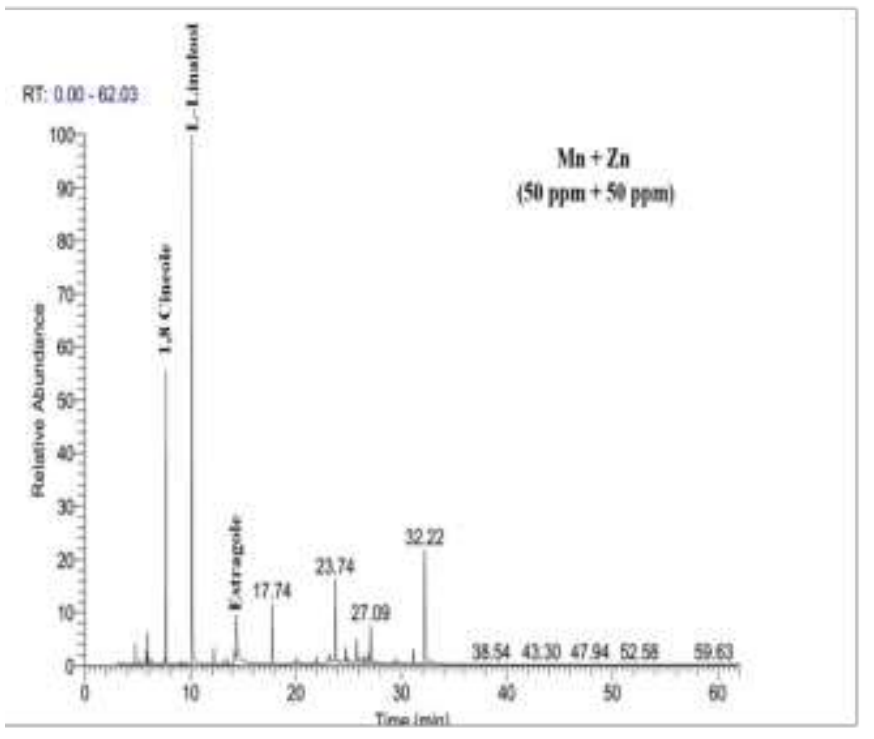

Fig (7): chromatogram of Ocimum basilicum, L. distilled from plants treated by $M n+2 n(50 \mathrm{ppm})$ during the second cut in the second season 2015 .

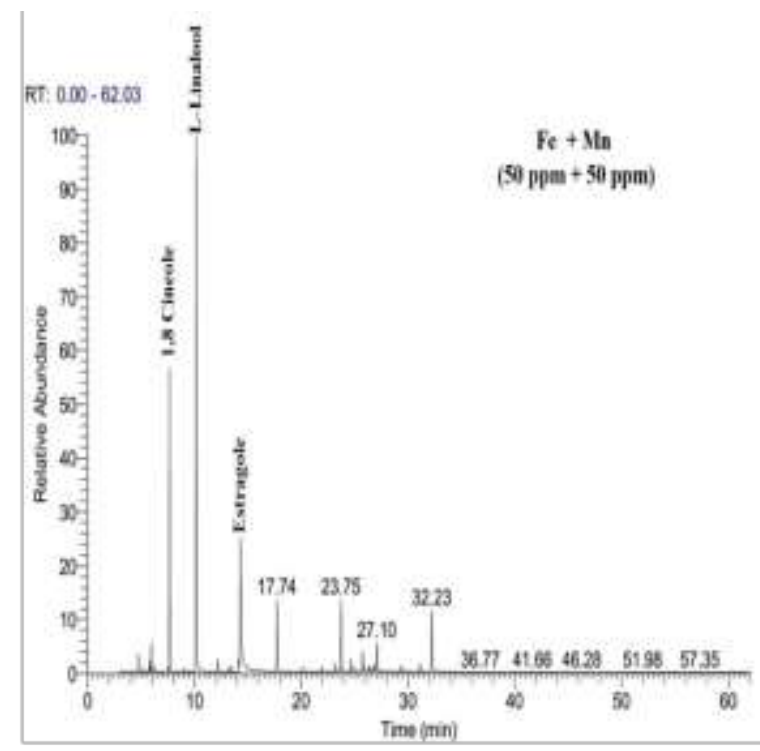

Fig (6): chromatogram of Ocimum basilicum, L. distilled from plants treated by $\mathrm{Fe}+\mathrm{Mn}(50 \mathrm{ppm})$ during the second cut in the second season 2015.

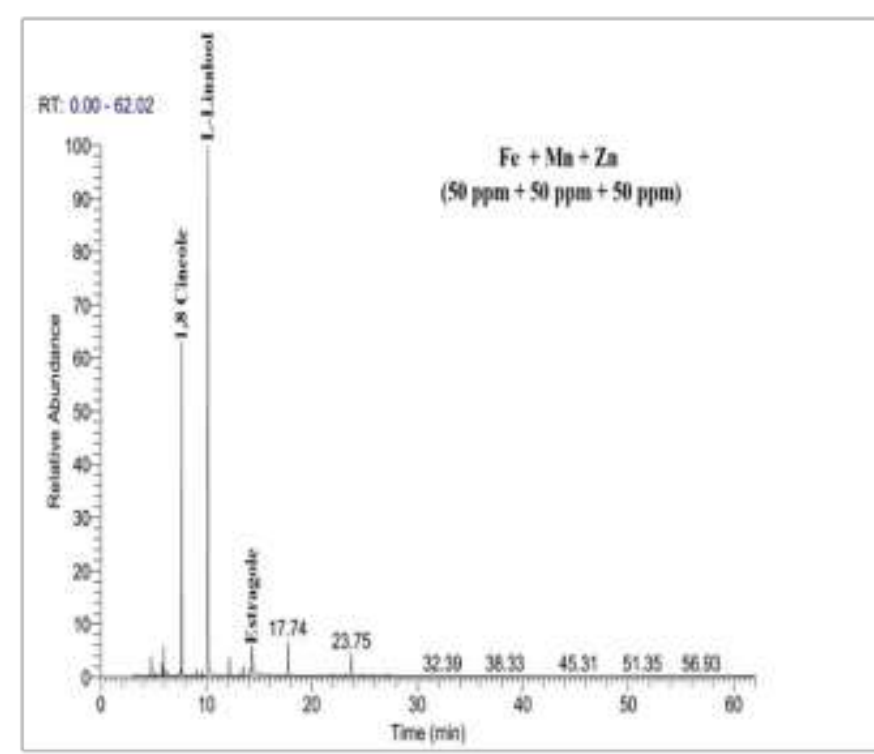

Fig (8): chromatogram of Ocimum basilicum, L. distilled from plants treated by $\mathrm{Fe}+2 \mathrm{Zn}+\mathrm{Mn}(50 \mathrm{ppm})$ during the second cut in the second season 2015 .

Egyptian J. Desert Res., 67, No. 1, 1-23 (2017) 
Table (7). The main components in essential oil of Ocimum basilicum plant by GC-Mass analysis during the second cut in the second season of 2015 .

\begin{tabular}{|c|c|c|c|c|c|c|c|c|}
\hline $\begin{array}{l}\text { Treatments } \\
\text { Compound }\end{array}$ & Control & $\mathbf{F e}$ & $\mathbf{Z n}$ & Mn & $\mathrm{Fe}+\mathrm{Zn}$ & $\mathrm{Fe}+\mathrm{Mn}$ & $M n+Z n$ & $\mathrm{Fe}+\mathrm{Mn}+\mathrm{Zn}$ \\
\hline$\alpha$-Thujene & - & - & - & - & - & - & - & 0.06 \\
\hline$\alpha$-Pinene & 2.41 & 2.76 & 2.55 & 2.53 & 1.67 & 2.25 & 2.49 & 3.04 \\
\hline$\alpha$-Phellandrene & - & - & - & 0.77 & - & - & - & - \\
\hline Camphene & 0.21 & 0.17 & 0.20 & - & 0.10 & 0.21 & 0.23 & 0.27 \\
\hline$\alpha$-Myrcene & 0.76 & 0.78 & 0.74 & 0.53 & 0.66 & 0.44 & 0.48 & 0.56 \\
\hline Sabinene & 0.65 & 0.89 & 0.73 & & 0.53 & 0.65 & 0.71 & 0.90 \\
\hline Camphor & 1.33 & 0.95 & 0.88 & 0.74 & 1.37 & 0.91 & 1.16 & 1.73 \\
\hline D-Limonene & 0.29 & 0.33 & 0.30 & 0.26 & 0.29 & 0.21 & 0.27 & 0.41 \\
\hline O-Cymene & - & - & - & - & 0.06 & - & - & 0.07 \\
\hline 1,8 Cineole & 12.79 & 20.74 & 13.17 & 18.59 & 23.28 & 17.59 & 16.88 & 25.66 \\
\hline $\begin{array}{l}\text { Trans Sabinene } \\
\text { Hydrate }\end{array}$ & 0.31 & 0.39 & 0.29 & 0.43 & - & 0.35 & 0.30 & 0.88 \\
\hline $\begin{array}{l}\text { Linalyl } \\
\text { Propionate }\end{array}$ & 0.31 & 0.37 & 0.32 & - & - & - & - & - \\
\hline L-Linalool & 27.52 & 35.98 & 28.16 & 35.40 & 42.29 & 38.06 & 37.11 & 52.69 \\
\hline Cis-Ocimene & 0.34 & - & - & - & 0.09 & - & - & 0.07 \\
\hline Ç-Terpinene & - & 0.19 & - & - & 0.12 & - & - & 0.12 \\
\hline$\alpha$-Terpineol & 0.65 & 1.11 & 0.97 & 1.28 & 2.60 & 1.22 & 1.30 & 1.05 \\
\hline 1-4-Terpineol & 0.48 & 1.27 & 0.60 & 0.94 & 1.49 & 0.50 & 0.49 & - \\
\hline$\alpha$-Terpinolene & - & - & 6.90 & - & 0.12 & - & - & 0.15 \\
\hline Linalool Oxide & - & - & - & - & 0.34 & - & - & 0.40 \\
\hline Estragole & 9.94 & 6.07 & 12.33 & 7.74 & 10.44 & 15.00 & 4.22 & 3.21 \\
\hline Bornyl Acetate & 3.69 & 3.68 & 5.02 & 4.44 & 3.43 & 5.56 & 4.57 & 3.48 \\
\hline 2-Oxabicyclo & 0.50 & - & 0.65 & 0.65 & - & - & 0.54 & 0.13 \\
\hline $\begin{array}{l}\text { Caryophyllene } \\
\text { Oxide }\end{array}$ & 0.96 & 0.60 & - & - & - & - & - & - \\
\hline $\begin{array}{l}\text { 1,2- } \\
\text { Cyclohexanediol }\end{array}$ & 0.83 & 0.53 & 0.95 & 0.44 & 0.36 & 0.43 & - & - \\
\hline Cyclohexane & 1.66 & 0.64 & 0.73 & 0.52 & 0.49 & 0.49 & 0.67 & 0.33 \\
\hline $\begin{array}{l}\text { Trans- } \\
\text { Caryophyllene }\end{array}$ & 1.20 & - & 2.27 & 0.61 & 0.49 & 0.67 & 0.60 & 0.28 \\
\hline$\alpha$-Copaene & - & - & - & - & 0.07 & - & - & 0.07 \\
\hline$\alpha$-Bourbonene & - & 0.15 & 0.18 & - & 0.09 & - & - & 0.10 \\
\hline Humulene & 1.53 & 1.06 & 1.91 & 1.22 & 0.45 & 1.02 & 1.22 & 0.25 \\
\hline Calarene & - & - & 0.23 & 0.21 & - & 0.16 & - & - \\
\hline Camphor & - & - & 0.75 & - & - & 0.52 & 0.45 & - \\
\hline Bicycle & 9.17 & 6.14 & - & 4.66 & 3.03 & 5.63 & 6.39 & - \\
\hline
\end{tabular}




\begin{tabular}{|c|c|c|c|c|c|c|c|c|}
\hline $\begin{array}{l}\text { Table (7). Cont. } \\
\text { D-Germacrene - }\end{array}$ & 3.52 & 2.16 & 3.56 & - & 0.31 & 1.71 & 1.97 & - \\
\hline $\begin{array}{l}\text { Trans-à- } \\
\text { Bergamotene }\end{array}$ & - & - & - & - & - & - & - & 2.35 \\
\hline $\begin{array}{l}\text { Trans-á- } \\
\text { Farnesene }\end{array}$ & 0.74 & - & 0.57 & 0.38 & 0.10 & - & - & 0.07 \\
\hline Azulene & 0.60 & 0.90 & 0.55 & 0.37 & - & 0.32 & 0.47 & - \\
\hline Cis-á-Farnesene & - & 0.41 & - & - & - & 0.37 & 0.50 & - \\
\hline Cyclohexane & - & - & - & - & - & 0.47 & 0.62 & 1.04 \\
\hline Naphthalene & 0.64 & 0.15 & 0.23 & 2.93 & - & 0.14 & 0.19 & - \\
\hline$\alpha$-Cadinol & 11.01 & 5.45 & & 10.23 & - & 5.46 & 9.97 & - \\
\hline (+) Spathulenol & & 0.15 & 0.19 & 0.26 & - & 0.16 & 0.25 & - \\
\hline Cubenol & 1.34 & 0.74 & 9.16 & 1.25 & - & 0.71 & 1.20 & - \\
\hline 1-Naphthalenol & - & - & - & 1.10 & - & - & - & - \\
\hline Cyclohexane & - & - & - & - & - & 0.60 & - & - \\
\hline Çmuurolene & 4.59 & - & 3.82 & - & 0.76 & - & 3.04 & 0.31 \\
\hline ç-Cadinene & - & - & - & - & - & 2.39 & - & - \\
\hline $\begin{array}{l}\text { Caryophyllene } \\
\text { Oxide }\end{array}$ & - & - & - & 0.23 & - & - & 0.87 & - \\
\hline Bicycle & - & - & - & - & 0.10 & - & 0.43 & - \\
\hline
\end{tabular}

Means having the same letter within the same column are not significantly different according to LSD for all-pairwise comparisons test at 5\% level of probability.

\section{Mineral Content}

\subsection{Macroelements percentage $(\mathrm{N}, \mathrm{P}$ and $\mathrm{K})$}

The results of table (8) indicate that there were differences in the percentage of $\mathrm{N}, \mathrm{P}$ and $\mathrm{K}$ in the leaves of sweet basil plant, as a result of spraying with microelements. Moreover, results show that the highest $\mathrm{N}, \mathrm{P}$ and $\mathrm{K}$ percentages per plant were observed in case of spraying Fe separately, comparing to $\mathrm{Zn}$ or $\mathrm{Mn}$ alone. Meantime, spraying plant with $\mathrm{Zn}+\mathrm{Fe}+\mathrm{Mn}$ together was the most effective treatment in increasing each of $\mathrm{N}, \mathrm{P}$ and $\mathrm{K}$ percentages per plant and these increases were significant in both cuts and seasons.

The obtained results for the effect of $\mathrm{Zn}$ on the minerals percentages are in harmony with these mentioned by Heidarian et al. (2011) on Glycine max plant and Abd El-Aziz and Balbaa (2007) on Salvia farinacea. They concluded that application of $\mathrm{Zn}$ increased the N, P and K percentages in leaves. Similar results for the positive effect of Mn were obtained by Abd ElAziz (2000) on basil plant and Eisa (2000) on fennel plantd. Who found that $\mathrm{Mn}$ application increased the $\mathrm{N}, \mathrm{P}$ and $\mathrm{K}$ percentage in plant leaves.

The positive effect of $\mathrm{Fe}$ on the percentages of $\mathrm{N}, \mathrm{P}$ and $\mathrm{K}$ are in harmony with those obtained by El-Mekawy et al. (2009) on Achillea fragrantissima and Nasiri et al. (2010) on Matricaria chamomilla. They

Egyptian J. Desert Res., 67, No. 1, 1-23 (2017) 
concluded that $\mathrm{Fe}$ application increased the $\mathrm{N}, \mathrm{P}$ and $\mathrm{K}$ percentage in plant leaves.

Table (8). Effect of some microelements on nitrogen, phosphorus, potassium percentages in leaves of Ocimumbasilicum during two seasons of 2014 and 2015.

\begin{tabular}{|c|c|c|c|c|c|c|}
\hline \multirow[b]{2}{*}{ Treatments } & \multicolumn{2}{|c|}{$\begin{array}{c}\text { Nitrogen } \\
\text { percentage }\end{array}$} & \multicolumn{2}{|c|}{$\begin{array}{l}\text { Phosphorus } \\
\text { percentage }\end{array}$} & \multicolumn{2}{|c|}{$\begin{array}{l}\text { Potassium } \\
\text { percentage }\end{array}$} \\
\hline & $\begin{array}{c}1^{\text {st }} \\
\text { Season }\end{array}$ & $\begin{array}{c}2^{\text {nd }} \\
\text { Season }\end{array}$ & $\begin{array}{c}1^{\text {st }} \\
\text { Season }\end{array}$ & $\begin{array}{c}2^{\text {nd }} \\
\text { Season }\end{array}$ & $\begin{array}{c}1^{\text {st }} \\
\text { Season }\end{array}$ & $\begin{array}{c}2^{\text {nd }} \\
\text { Season }\end{array}$ \\
\hline Control & $1.117 \mathrm{G}$ & $1.230 \mathrm{G}$ & $1.233 \mathrm{G}$ & $1.400 \mathrm{G}$ & $.124 \mathrm{E}$ & $0.136 \mathrm{E}$ \\
\hline $\mathrm{Fe}(5$ & $00 \mathrm{D}$ & $087 \mathrm{D}$ & $200 \mathrm{D}$ & $2.333 \mathrm{D}$ & $224 \mathrm{C}$ & $.247 \mathrm{C}$ \\
\hline Mn ( & $00 \mathrm{~F}$ & $420 \mathrm{~F}$ & $467 \mathrm{~F}$ & $1.566 \mathrm{~F}$ & $138 \mathrm{E}$ & $.150 \mathrm{E}$ \\
\hline $\mathbf{Z n}$ & $1.747 \mathrm{E}$ & $1.923 \mathrm{E}$ & $1.967 \mathrm{E}$ & $2.167 \mathrm{E}$ & $.195 \mathrm{D}$ & $0.215 \mathrm{D}$ \\
\hline ppm) & $2.250 \mathrm{BC}$ & $2.473 \mathrm{BC}$ & $2.533 \mathrm{~B}$ & $2.767 \mathrm{BC}$ & $0.259 \mathrm{~B}$ & $0.285 \mathrm{~B}$ \\
\hline $\mathrm{Fe}+2$ & $2.337 \mathrm{~B}$ & $2.570 \mathrm{~B}$ & $2.633 \mathrm{~B}$ & $2.867 \mathrm{~B}$ & $0.269 \mathrm{~B}$ & $0.296 \mathrm{~B}$ \\
\hline Mn- & $163 \mathrm{C}$ & $2.380 \mathrm{C}$ & $2.367 \mathrm{C}$ & $2.667 \mathrm{C}$ & $0.238 \mathrm{C}$ & $0.261 \mathrm{C}$ \\
\hline $\mathrm{Fe}+\mathrm{Mn}+\mathrm{Zn}(50 \mathrm{ppm})$ & $2.460 \mathrm{~A}$ & $2.707 \mathrm{~A}$ & $2.833 \mathrm{~A}$ & $3.033 \mathrm{~A}$ & $0.290 \mathrm{~A}$ & $0.318 \mathrm{~A}$ \\
\hline
\end{tabular}

Means having the same letter within the same column are not significantly different according to LSD for all-pairwise comparisons test at 5\% level of probability.

The simulative effect of the mixture of $\mathrm{Zn}, \mathrm{Mn}$ and Fe application on the mineral percentage (N, P and K) was also reported by Said-Al-Ahl and Mahmoud (2010) on Ocimum basilicum plant. They found that, spraying plants with $\mathrm{Zn}, \mathrm{Mn}$ and $\mathrm{Fe}$ either alone or in mixture increased the contents of $\mathrm{N}, \mathrm{P}$ and $\mathrm{K}$ percentage in plant tissue, and the best mixture was the application of the three microelements together to plants, followed by the coupling of $\mathrm{Zn}+\mathrm{Mn}$ or $\mathrm{Mn}+\mathrm{Fe}$. The stimulating effect of $\mathrm{Zn}, \mathrm{Mn}$ and $\mathrm{Fe}$ may be due to their effect on enhancing the plant metabolism (Amberger, 1974 and Miller et al., 1995).

\subsection{Microelements concentration in leaves ( $\mathrm{Zn}, \mathrm{Mn}$ and $\mathrm{Fe})$}

Data in table (9) presents that, the effect of spraying plants with $\mathrm{Zn}$, $\mathrm{Mn}$ and $\mathrm{Fe}$ on the concentrations of these elements in the leaves of sweet basil plant. It is obvious that $\mathrm{Zn}, \mathrm{Mn}$ and Fe sprayed each alone resulted in highly significant increase of $\mathrm{Zn}, \mathrm{Mn}$ and Fe concentrations as compared with the control. This means that, $\mathrm{Fe}$ was the most effective element. Also, all microelements mixtures resulted in high significant increase of $\mathrm{Zn}, \mathrm{Mn}$ and $\mathrm{Fe}$ concentrations compared with each element separately. It is also obvious that $\mathrm{Zn}+\mathrm{Fe}$ had produced significantly higher values of $\mathrm{Zn}, \mathrm{Mn}$ and $\mathrm{Fe}$ than $\mathrm{Zn}+\mathrm{Mn}$ or $\mathrm{Mn}+\mathrm{Fe}$. The mixture of the three elements had significantly increased $\mathrm{Zn}, \mathrm{Mn}$ and $\mathrm{Fe}$ concentrations compared with any 
single elements. The treatment of $\mathrm{Zn}+\mathrm{Mn}+\mathrm{Fe}$ together gave the highest values followed by $\mathrm{Zn}+\mathrm{Fe}, \mathrm{Mn}+\mathrm{Fe}$ and $\mathrm{Zn}+\mathrm{Mn}$.

Similar findings for the positive effect of zinc in $\mathrm{Zn}, \mathrm{Mn}$ and $\mathrm{Fe}$ concentrations were stated by Grejtovsky et al. (2006) on Matricaria chamomilla., Abd El-Aziz and Balbaa (2007) on Salviafa rinacea and Akhtar et al. (2009) on Mentha pipeta. They found that, the concentrations of $\mathrm{Zn}, \mathrm{Mn}$ and $\mathrm{Fe}$ were significantly increased as a result of $\mathrm{Zn}$ application.

Table (9). Effect of some microelements on $\mathrm{Zn}, \mathrm{Mn}$ and Fe concentrations in leaves of Ocimum basilicum, during two seasons of 2014 and 2015.

\begin{tabular}{|c|c|c|c|c|c|c|}
\hline \multirow[t]{2}{*}{ Characters } & \multicolumn{2}{|c|}{ Iron (ppm) } & \multicolumn{2}{|c|}{ Manganese (ppm) } & \multicolumn{2}{|c|}{ Zinc (ppm) } \\
\hline & $\begin{array}{c}1^{\text {st }} \\
\text { Season }\end{array}$ & $\begin{array}{c}2^{\text {nd }} \\
\text { Season }\end{array}$ & $\begin{array}{c}1^{\text {st }} \\
\text { Season }\end{array}$ & $\begin{array}{c}2^{\text {nd }} \\
\text { Season }\end{array}$ & $\begin{array}{c}1^{\text {st }} \\
\text { Season }\end{array}$ & $\begin{array}{c}2^{\text {nd }} \\
\text { Season }\end{array}$ \\
\hline (distilled & $188.61 \mathrm{H}$ & $207.47 \mathrm{H}$ & $47.68 \mathrm{H}$ & $52.44 \mathrm{H}$ & $37.51 \mathrm{H}$ & $41.26 \mathrm{H}$ \\
\hline $\mathrm{Fe}(50 \mathrm{ppm})$ & $321.57 \mathrm{E}$ & $353.73 \mathrm{E}$ & $81.28 \mathrm{E}$ & $89.41 \mathrm{E}$ & $63.95 \mathrm{E}$ & $70.34 \mathrm{E}$ \\
\hline Mn (50 ppm) & $226.33 \mathrm{G}$ & $248.96 \mathrm{G}$ & $57.21 \mathrm{G}$ & $62.93 \mathrm{G}$ & $45.01 \mathrm{G}$ & $49.51 \mathrm{G}$ \\
\hline Zn (50 ppm) & $293.75 \mathrm{~F}$ & $323.12 \mathrm{~F}$ & $74.25 \mathrm{~F}$ & $81.67 \mathrm{~F}$ & $58.41 \mathrm{~F}$ & $64.25 \mathrm{~F}$ \\
\hline $\mathrm{Fe}+\mathrm{Mn}(50 \mathrm{ppm})$ & $371.01 \mathrm{C}$ & $408.11 \mathrm{C}$ & $93.78 \mathrm{C}$ & $103.16 \mathrm{C}$ & $73.78 \mathrm{C}$ & $81.16 \mathrm{C}$ \\
\hline $\mathrm{Fe}+\mathrm{Zn}(50 \mathrm{ppm})$ & $388.49 \mathrm{~B}$ & $427.34 \mathrm{~B}$ & $98.20 \mathrm{~B}$ & $108.00 \mathrm{~B}$ & $77.26 \mathrm{~B}$ & $84.98 \mathrm{~B}$ \\
\hline Mn+Zn (50 ppm) & $356.87 \mathrm{D}$ & $392.56 \mathrm{D}$ & $90.20 \mathrm{D}$ & $99.23 \mathrm{D}$ & $70.96 \mathrm{D}$ & $78.07 \mathrm{D}$ \\
\hline $\mathrm{Fe}+\mathrm{Mn}+\mathrm{Zn}(50 \mathrm{ppm})$ & $408.84 \mathrm{~A}$ & $449.72 \mathrm{~A}$ & $103.34 \mathrm{~A}$ & $113.60 \mathrm{~A}$ & $81.30 \mathrm{~A}$ & $89.43 \mathrm{~A}$ \\
\hline
\end{tabular}

Means having the same letter within the same column are not significantly different according to LSD for all-pairwise comparisons test at 5\% level of probability.

The obtained results for the effect of $\mathrm{Mn}$ on $\mathrm{Zn}, \mathrm{Mn}$ and $\mathrm{Fe}$ concentrations are in accordance with those of Pande et al. (2007) on mint plant and Said-Al-Ahl and Omer (2009) on Coriandrum sativum. They stated that spraying plants with $\mathrm{Mn}$ at $50 \mathrm{ppm}$ increased $\mathrm{Zn}, \mathrm{Mn}$ and $\mathrm{Fe}$ concentrations in the leaves.

The presented data for the effect of iron agreed with those of Baloch et al. (2008) and Abd El-Wahab (2008), who reported that micronutrients such as $\mathrm{Fe}, \mathrm{Mn}$ and $\mathrm{Zn}$ have important roles in plant growth and yield of aromatic and medicinal plants. The activator effect of the mixture of $\mathrm{Fe}$, $\mathrm{Mn}$ and $\mathrm{Zn}$ application on the mineral concentrations (Fe, Mn and $\mathrm{Zn}$ ) was also reported by Abd El-Aziz (2000) on basil plant and Eisa (2000) on fennel plant. They stated that spraying with $\mathrm{Zn}, \mathrm{Mn}$ and Fe singly or in mixture at $50 \mathrm{ppm}$ caused an increasing in these microelements in the plant tissues. These results may be due to the effect of these elements on the plant growth as well as the leaves yield per plant.

Egyptian J. Desert Res., 67, No. 1, 1-23 (2017) 


\section{REFERENCES}

Abd El-Aziz, A.H.S. (2000). Effect of some fertilization treatments on the growth and volatile oil yield on basil plant. Ph.D. Thesis, Fac. Agric., Zagazig Univ.

Abd El-Aziz, N.G. and L.K. Balbaa (2007). Influence of tyrosine and zinc on growth, flowering and chemical constituents of Salvia farinacea plants. Journal of Applied Sciences Research, 3(11): 1479-1489.

Abd El-Hady, B.A. (2007). Effect of zinc application on growth and nutrient uptake of barley plant irrigated with saline water. Journal of Applied Sciences Research, 3(6): 431-436.

Abd El-Wahab, M.A. (2008). Effect of some trace elements on growth, yield and chemical constituents of Trachyspermum ammi, L. (Ajowan) plants under Sinai conditions. Research Journal of Agricultural and Biology Sciences, 4(6): 717-724.

Akhtar, N., M.A. Sarker, H. Akhter and Nada M. Katrun (2009). Effect of planting time and micronutrient as zinc chloride on the growth, yield and oil content of Mentha piperita. Bangladesh Journal of Scientific and Industrial Research, 44: 125-130.

Amberger, A. (1974). Micronutrients dynamics in the soil and function in plant metabolism. Proc. Egypt. Bot. Soc. Workshop. I, Cairo.

Analytical Software (1985). Data analysis software for researchers 1985.

Aziz, E.E. and S.E. El-Sherbeny (2004). Effect of some macro and micronutrients on growth and chemical constituents of Sideritis montana, L. as a new plant introduced into Egypt. Arab Uni. J. Agric. Sci., Ain Shams Univ., Cairo, Egypt, 12 (1): 391-403.

Baloch, Q.B., Q.I. Chachar, M.N. Tareen (2008). Effect of foliar application of macro and micro nutrients on production of green chilies (Capsicum annuum L.). J. Agric. Tech., 4 (2): 177-184.

British Pharmacopoeia (1936). Determination of volatile oil in drugs. Published by the Pharmaceutical Press, London.

Brown, J.D. and D. Lilleland (1946). Rapid determination of potassium and sodium in plant material and soil extracts by flam photometry. Proc. Amer. Soc., Hort. Sci., 48: 341-346.

Bunzen, J., N. Guichard, P. Labbr, J. Prevot and J.Trenchant (1969). In "Practical Manual of Gas Chromatography". (J. Ttenchant, Ed.). El-Seivier, Publ. Comp., Amesterdam, Netherland.

Chaman, H.D. and P.E. Pratt (1961). In " Methods of Analysis for Soil, Plants and Water". Univ. Calif. Agric., USA.

Dewidar, A.A.A. (2002). Physiological studies on digitalis plant. M.Sc. Thesis, Fac. Agric., Moshtohor Zagazig Univ., Banha Branch.

Eisa, E.A.E. (2000). Effect of some fertilization treatments on the growth and volatile oil yield on fennel plant. M.Sc. Thesis, Fac. Agric., Zagazig Univ. 
El-Fouly, M.M., Z.M. Mobarak and Z.A. Salama (2002). Micronutrient foliar application increases salt tolerance of tomato seedlings. Proc. Sym. Techniques to Control Salination for Horticultural Productivity. Acta Hort. 573: 377-385.

El-Mekawy, M.A., M.D. El-Deep, A.E. El-Zahwy and H.M. Huwishel (2009). Effect of irrigation intervals and salinity of irrigation water on growth, and chemical composition of Achillea santolina L. plants. J. Agric. Res. Tanta Univ., 32 (1): 149-172.

El-Sawahly, M.A.A.K. (2000). Effect of some fertilization treatments on the growth and active ingredients of Borago officinalis, L. plant. M.Sc. Thesis, Fac. Agric., Zagazig Univ.

El-Sawi, S.A. and M.A. Mohamed (2002). Cumin herb as a new source of essential oils and its response to foliar spray with some microelements. J. Food Chemistry, 77: 75-80.

Gauch, H.G. (1957). Mineral nutrition of plants. Ann. Rev. Plant physiol., 8: 31.

Gharib, F.A. (2001). Morphological and biochemical responses of Tagetes minuta L. plants to foliar application of nicotinamide and micronutrient. Egypt. J. Botany. 41(2): 227-34.

Gohain, T. and A.C. Barbora (2000). Effect of different sources of magnesium on yield and quality of tea (Camellia Sinensis, L.). Soil and Fertilizers, 63 (9).

Grejtovsky, A., K. Markusova and A. Eliasova (2006). The response of chamomile (Matricaria chamomilla, L.) plants to soil zinc supply. Plant, Soil and Environment, 52: 1-7.

Hashem, H.A. (2007). Effect of some fertilization treatments on Thymus vulgaris plant cultivated under north Sinai conditions. M.Sc. Thesis, Fac. Agric., Zagazig Univ.

Heidarian A.R., H. Kord, K.Mostafavi, A.P. Lak and F.A. Mashhadi (2011). Investigating $\mathrm{Fe}$ and $\mathrm{Zn}$ foliar application on yield and its components of soybean (Glycine $\max$ (L) Merr.) at different growth stages. Journal of Agricultural Biotechnology and Sustainable Development, 3: 189-197.

Hendawy, S.F. and Kh.A. Khalid (2005). Response of sage (Salvia officinalis, L.) plants to zinc application under different salinity levels. J. Appl. Sci. Res., 1: 147-155.

Hoftman, E. (1967). Chromotography, Reinhild. Corp., $2^{\text {nd }}$ Ed., p. 208-515.

Kalidasu, G., C. Sarada and T. Yellamanda-Reddy (2008). Influence of micronutrients on growth and yield of coriander (Coriandrum sativum) in rainfed vertisols. Journal of Spices and Aromatic Crops, 17 (2): 187- 189.

Kassem, A.H. (2002). Effect of planting distances and some trace elements on rosemary plant. Ph.D. Thesis., Fac. Agric., Cairo Univ.

Egyptian J. Desert Res., 67, No. 1, 1-23 (2017) 
Koch, F.C. and T.L. Mc-Meekin (1924). A new direct nesslarization microKjeldahl method and modification of the Nesslar folia reagent for ammonia. J. Amer. Chem. Soc., 46: 2066.

Malakouti, M.J. and M.H. Tehrani (1999). In "Effect of Micronutrients in Yield Increase and Improvement of Crops Quality". Tarbiat Modarres University Press.

Marotti, M., R. Piccaglia and E. Giovanelli (1996). Differences in essential oil composition of basil (Ocimum basilicum, L.) Italian cultivars related to morphological characteristics. J. Agric. Food Chem., 44: 3926-3929.

Marschner, H. (1998). In "Mineral Nutrition of Higher Plants". 2nd ed. Academic Press, Harcourt Brace and Company, Publisher London, San Diego, New York, Boston, Sydney, Tokyo, Toronto, 864 pp.

Mengel, K. and F.A. Kirkby (1978). In "Principles of Plant Nutrition". $3^{\text {rd }}$ ed. Bern International Potash Institute.

Miller, G.W., I.J. Huang, G.W. Welkie and J.C. Pushmik (1995). In "Function of Iron in Plants with Special Emphasis on Chloroplasts and Photosynthetic Activity". (J. Abadia Ed.). Iron Nutrition in Soils and Plants. Kluwer Academic Publishers, Dordecht, p.19-28.

Nasiri, Y., S. Zehtab-Salmasi, S. Nasrullahzadeh, N. Najafi and K. Ghassemi-Golezani (2010). Effects of foliar application of micronutrients $(\mathrm{Fe}$ and $\mathrm{Zn}$ ) on flower yield and essential oil of chamomile (Matricaria chamomilla, L.). Journal of Medicinal Plants Research, 4: 1733-1737.

Nikolic, M. and R. Kastori (2000). Effect of bicarbonate and Fe supply on Fe nutrition of grapevine. J. Plant Nutr., 23: 1619-1627.

Osińska, M., E. Rosłon and W. Drzewiecka (2012). The evaluation of quality of selected cultivars of parsley (Petroselinum sativum L. ssp. crispum). Acta Sci. Pol., Hortorum Cultus., 11(4): 47-57.

Ozcan, M. and J.C. Chalchat (2002). Essential oil composition of Ocimum basilicum, L. and Ocimum minimum, L. in Turky. Czech J. Food Sci., 20: 223-2280.

Pande, P., M. Anwar, S. Chand, V.K. Yadav and D.D. Patra (2007). Optimal level of iron and zinc in relation to its influence on herb yield and production of essential oil in menthol mint. Communications in Soil Science and Plant Analysis, 38 (5 \& 6): 561-578.

Piagentini, A.M., D.R. Guemes and M.E. Pirovani (2002). Sensory characteristics of fresh cut spin ach preserved by combined factors methodology. J. Food Sci., 64 (4): 1544-1549.

Reffat, A.M. and L.K. Balbaa (2001). Yield and quality of lemongrass plants (Cymbopogon flexusus Stapf) in relation to foliar application of some vitamins and microelements. Egyptian J. Hort., 28 (1): 4157. 
Said-Al Ahl, H.A.H. and A. Mahmoud (2010). Effect of Boron and / or iron foliar application on growth and essential oil of sweet basil (Ocimum basilicum, L.) under salt stress. Ozean Journal of Applied Science, 3: 97-111.

Said-Al-Ahl, H.A.H. and E.A. Omer (2009): Effect of spraying with zinc and / or iron on growth and chemical composition of coriander (Coriandrum sativum, L.) harvested at three stages of development. Journal of Medicinal Food Plants, 1: 30-46.

Sajjadi, S.E. (2006). Analysis of the essential oils of two cultivated basil (Ocimum basilicum, L.) from Iran. Daru, 14 (3): 128-130.

Snedecor, G.W. and W.G. Cochran (1980). Statistical Methods $7^{\text {th }}$ ed. Iowa State Univ. Press. Ames. Iowa, USA.

Telci, I., E. Bayram, G. Yilmaz and B. Avci (2006). Variability in essential oil composition of Turkish basils (Ocimum basilicum ). Biochem. Syst. Ecol., 34: 489-497.

Troug, E. and A. Mayer (1939). Improvement in the direness colorimetric method for phosphorus and arsenic. Ind. Eng. Chem. Anal., Ed. 1: 136-139.

Vina, A. and E. Murillo (2003). Essential oil composition from twelve varieties of basil (Ocimum spp.) grown in Colombia. J. Braz. Chem. Soc., 14 (5): 744-749.

Younis, A., A. Riaz, M. Sajid, N. Mushtaq, M. Ahsan and M. Nadeem (2013). Foliar application of macro- and micronutrients on the yield and quality of Rosa hybrid, cvs. Cardinal and Whisky Mac. African Journal of Biotechnology, 12 (7): 702-708.

Zehtab-Salmasi, S., F. Heidari and H. Alyari (2008). Effects of microelements and plant density on biomass and essential oil production of peppermint (Mentha piperita, L.). Plant Science Research, 1: 24-26.

Egyptian J. Desert Res., 67, No. 1, 1-23 (2017) 


\section{تأثير العناصر الصغرى على النمو والمحصول والتركيب الكيماوي لنبات الريحان}

راينة مرتضي خاطر * ووفاء حامد عبد العليم عبد الله

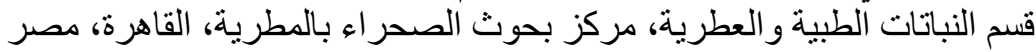

أجريت هذه الدراسة في محطة بحوث القنطرة شرق التابعة لمركز بحوث الصحراء

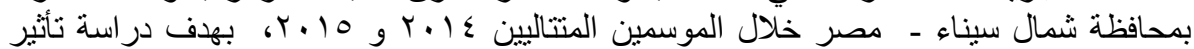

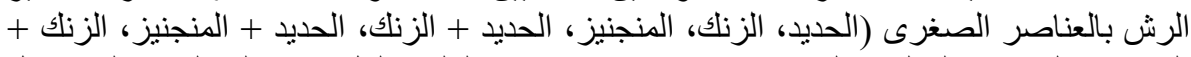

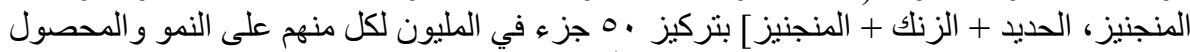

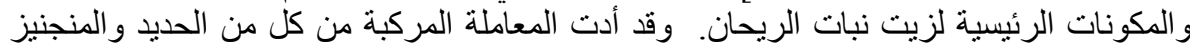

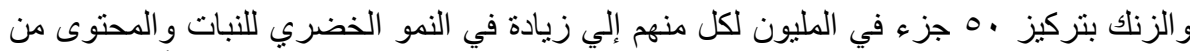

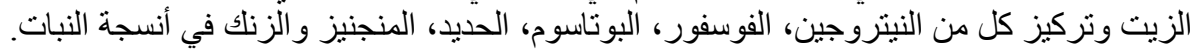

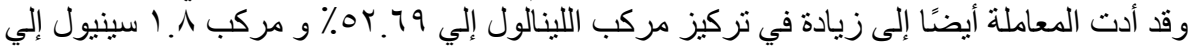
$\%$ \% $\%$. 74 